\title{
CHARACTER OF PROTEST POLITICAL MOBILIZATION IN THE REGIONAL PUBLIC SPACE OF VOLGOGRAD REGION ${ }^{1}$
}

\author{
Sergey D. Gavrilov \\ Volgograd State University, Volgograd, Russian Federation \\ Kirill M. Makarenko \\ Volgograd State University, Volgograd, Russian Federation
}

\begin{abstract}
Introduction. The article is devoted to the analysis of the protest political mobilization in the regional political space of Volgograd region. Particular attention is paid to the study of the main conditions and causes of protest activity in the context of implementing public policy in Volgograd region. The relevance of the problem field is due to the need for a political analysis of the characteristics of the population mobilization at the regional level, including their comparison with federal trends. Methodology and methods. The authors conceptualize political mobilization on the basis of the theoretical principles of the theory of collective behavior of G. Blumer, E. Hoffer, T. Garr and the rational basis for the mobilization of D. Gupt. The methodological basis of the study is the theory of collective action (Ch. Tilly), on the basis of which it is concluded that political mobilization is defined as a combination of institutional and social conditions that allow actors to rationally evaluate transaction costs and possible gains from mobilization actions. The analysis of the regional public policy system is based on the conclusions contained in the works of Yu.O. Gaivoronsky, S.I. Morozov, S.A. Pankratov. The empirical basis of the study is the public opinion polls of the Levada Center, expert and analytical materials on the state of protest activity of the Institute of Regional Expertise, as well as the results of monitoring data from Internet resources obtained with the direct participation of the authors in March 2020. Analysis. The modern Russian socio-political system is a synthesis of two opposites: a hermetically "closed" institutional political structure, which is determined by the situation of internal uncertainty, and an active social component. At the same time, the specifics of the regional public space of Volgograd Region is a combination of the subject composition of the institutional design of the regional political regime based on copying the features of the federal regime, as well as the diversity of the regional themes of socio-political protest. Based on the results obtained by the case-study method, it was found that the protest dynamics in Volgograd region show a downward trend, however, any manifestations of public protest activity in the region implicitly imply a political nature in direct proportion to the number of participants: the greater the number of participants in the protest stocks, the higher the degree of its politicization. Results. According to the results of the study, it was revealed that the protest political mobilization in the public space of Volgograd region is characterized by: firstly, the prevalence of regional problems over federal ones in the protest discourse; secondly, the lack of strong institutional structures that can mobilize material and organizational resources; thirdly, a critically low number of protesters; fourthly, the spontaneous nature of mobilization. A special feature of political mobilization in the regional dimension is the low social potential of the protest and the lack of effective mechanisms for political and communicative interaction between government institutions and the population of Volgograd region on a specific range of problems of a public nature. In order to overcome the shortcomings of dialogue communication, within the framework of representative democracy, the authors propose recommendations for the main actors of the public political space (regional authorities, expert community and civil society institutions).

Key words: political mobilization, political activity, protest potential, public space, public policy institutions, Volgograd region.

Citation. Gavrilov S.D., Makarenko K.M. Character of Protest Political Mobilization in the Regional Public Space of Volgograd Region. Vestnik Volgogradskogo gosudarstvennogo universiteta. Seriya 4. Istoriya. Regionovedenie. Mezhdunarodnye otnosheniya [Science Journal of Volgograd State University. History. Area Studies. (0) International Relations], 2020, vol. 25, no. 3, pp. 192-203. (in Russian). DOI: https://doi.org/10.15688/jvolsu4.2020.3.17
\end{abstract}




\title{
ХАРАКТЕР ПРОТЕСТНОЙ ПОЛИТИЧЕСКОЙ МОБИЛИЗАЦИИ В РЕГИОНАЛЬНОМ ПУБЛИЧНОМ ПРОСТРАНСТВЕ ВОЛГОГРАДСКОЙ ОБЛАСТИ ${ }^{1}$
}

\author{
Сергей Дмитриевич Гаврилов \\ Волгоградский государственный университет, г. Волгоград, Российская Федерация
}

\section{Кирилл Михайлович Макаренко}

Волгоградский государственный университет, г. Волгоград, Российская Федерация

\begin{abstract}
Аннотация. Введение. Статья посвящена анализу протестной политической мобилизации в региональном политическом пространстве Волгоградской области. Особое внимание уделяется исследованию основных условий и причин протестной активности в контексте реализации публичной политики в Волгоградской области. Актуальность проблемного поля обусловлена необходимостью политологического анализа характеристик мобилизации населения на региональном уровне, в том числе их сравнение с общефедеральными тенденциями. Методология и методы. Авторы концептуализируют политическую мобилизацию на основе теоретических положений теории коллективного поведения Г. Блумера, Э. Хоффера, Т. Гарра и рациональных оснований мобилизации Д. Гупта. Методологическую основу исследования составляет теория коллективного действия (Ч. Тилли), на основе которой делается вывод о том, что политическая мобилизация определяется как совокупность институциональных и социальных условий, позволяющих акторам рационально оценить транзакционные издержки и возможные приобретения от мобилизационных действий. Анализ региональной системы публичной политики базируется на выводах, содержащихся в работах Ю.О. Гайворонского, С.И. Морозова, С.А. Панкратова. Эмпирической основой исследования выступают опросы общественного мнения населения «Левада-центра», экспертно-аналитические материалы о состоянии протестной активности $\mathrm{AHO}$ «Институт региональной экспертизы», а также результаты мониторинга данных интернет-ресурсов, полученных при непосредственном участии авторов в марте 2020 года. Анализ. Современная российская общественно-политическая система представляет собой синтез двух противоположностей: герметично «закрытую» институциональную политическую структуру, которая определена ситуацией внутренней неопределенности, и активную социальную составляющую. Вместе с тем специфика регионального публичного пространства Волгоградской области представляет собой совокупность субъектного состава институционального дизайна регионального политического режима, основанного на копировании черт федерального режима, а также многообразие региональной тематики общественно-политического протеста. На основе результатов, полученных методом case-study, установлено, что протестная динамика в Волгоградской области демонстрирует нисходящий тренд, вместе с тем, любые проявления публичной протестной активности в регионе имплицитно подразумевают политический характер в прямой пропорциональной зависимости от количества участников: чем больше количество участников протестной акции, тем выше степень ее политизации. Результаты. По итогам проведенного исследования выявлено, что протестная политическая мобилизация в публичном пространстве Волгоградской области характеризуется: во-первых, превалированием региональных проблем над федеральными в протестном дискурсе; во-вторых, отсутствием сильных институциональных структур, способных мобилизовать материальные и организационные ресурсы; в-третьих, критически низким количеством протестующих; в-четвертых, стихийным характером мобилизации. Особой чертой политической мобилизации в региональном измерении является низкий социальный потенциал протеста и отсутствие действенных механизмов политико-коммуникативного взаимодействия между институтами власти и населением Волгоградской области по определенному кругу проблем публичного характера. С целью преодоления недостатков диалогового общения, в рамках представительной демократии авторами предложены рекомендации для основных акторов публичного политического пространства (органов региональной власти, экспертного сообщества и институтов гражданского общества). С.Д. Гаврилов провел анализ регионального пространства публичной политики, интерпретировал результаты анализа протестной активности Волгоградской области, сформулировал рекомендации основным акторам регионального политического процесса. К.М. Макаренко систематизировал теоретико-методологические подходы к анализу политической мобилизации, провел анализ эмпирических данных «Левада-центра» и мониторинг данных региональных СМИ.
\end{abstract}


Ключевые слова: политическая мобилизация, политическая активность, протестный потенциал, публичное пространство, институты публичной политики, Волгоградская область.

Цитирование. Гаврилов С. Д., Макаренко К. М. Характер протестной политической мобилизации в региональном публичном пространстве Волгоградской области // Вестник Волгоградского государственного университета. Серия 4, История. Регионоведение. Международные отношения. - 2020. - Т. 25, № 3. C. 192-203. - DOI: https://doi.org/10.15688/jvolsu4.2020.3.17

Введение. Проблема политической мобилизации перманентно актуализируется в связи с участившимися случаями коллективных действий как в России (в том числе в ее регионах), так и мире. В ретроспективе последних лет фиксируется целый ряд событий, исход которых показывает значимость социальных действий масс граждан, ставящих перед собой единую политическую (и не только) цель. За последнее десятилетие в России случались периоды пика и спада политической протестной активности - от акций «за честные выборы» в 2011-2012 гг. до «мусорной» и «пенсионной» реформ. Вместе с тем общефедеральная повестка часто уступала первенство отдельным региональным кейсам, таким как митинги против строительства никелевого завода в Урюпинске Волгоградской области, протесты по поводу экологической ситуации в Архангельской области, митинги против строительства храма в Екатеринбурге, акции «Допускай», связанные с выборами в Московскую городскую Думу и т. д. В связи с этим наиболее актуальным становится анализ региональной специфики политической протестной мобилизации в публичном пространстве.

Вместе с тем политическое пространство Волгоградского региона обусловлено интеракциями институциональных акторов в контексте существующих формальных и неформальных практик управления, в том числе мобилизации, а также механизмов и технологий достижения общественно-политического консенсуса с целью оптимизации системы политико-административного управления. Особый научный интерес заключен в том числе в проблематике определения позиции Волгоградской области в общефедеральной системе публичной политики с точки зрения протестной мобилизации населения.

Методология и методы исследования. Политическая мобилизация - важный общественно-политический феномен, особое внимание к которому было уделено во второй половине XX в., что обусловливалось ростом общественных движений различной направленности, начиная от социальных движений за гражданские права, заканчивая экологическими активистами. В связи с этим выработалось несколько ключевых подходов к изучению причин, форм и циклов политической мобилизации:

- теория коллективного поведения, базирующаяся на том, что основной причиной политической мобилизации выступает социальная напряженность. В данном подходе хотелось бы выделить исследования Г. Блумеpa, одного из основоположников данной традиции в изучении групповой активности как результата объединения индивидов на основе общих экспектаций ради выполнения коллективных целей [1]. Э. Хоффер оригинально представил структуру и причины образования масс в работе «Человек убежденный» [18]. Особое внимание автора привлекло исследование Т. Гарра, опубликованное в работе «Почему люди бунтуют?». Фундаментальным тезисом работы послужило выражение, согласно которому протесты (протестная мобилизация) являются следствием разрыва между «ценностными экспектациями и ценностными возможностями», который возникает в результате резкого падения уровня жизни граждан, следующего после периода экономического роста [3];

- рациональный подход, базирующийся на институциональной природе политической мобилизации, где участие в социальном движении является результатом рациональной оценки сложившейся ситуации и сформированной ресурсной базы $[5$, с. 10]. Также внимания заслуживают положения, обоснованные в работе «Понимая терроризм и политическое насилие» Д. Гупта, согласно которым индивид рационализирует участие в коллективных действиях, оценивая экономические выгоды и субъективные издержки от включения в подобные акции [20]. 
Методологическую основу исследования составляет теория коллективного действия, представляющая собой логичный синтез как психологических, так и институциональных оснований мобилизационных действий. Авторы придерживаются трактовки американского исследователя Ч. Тилли, определившего в качестве центрального места изучения политической мобилизации - структуру политических возможностей, то есть тех институциональных и социальных условий, позволяющих акторам рационально оценить транзакционные издержки и возможные приобретения от мобилизационных действий [16]. В качестве конкретных методов исследования используются методы кейс-стади, позволяющие провести системный анализ конкретных практик протестной мобилизации, а также сводка и группировка материалов статистического наблюдения, создающие возможность для обработки информации и представления эмпирически значимых выводов. Помимо этого, анализ эмпирической информации основывается на количественных методах сбора и обработки данных, представленных аналитическим центром «Левада-центр» и «Институтом региональной экспертизы».

Анализ. Логика изучения политической мобилизации в модернистском ключе детерминирует понимание изучаемого феномена как необходимого условия крупных общественных изменений. Политическая мобилизация представляет собой процесс вовлечения индивидов и социальных групп в различные формы политической активности. При этом форма активности, ее тип и характер определяются рядом критериев: 1) объемом имеющихся материальных, темпоральных, социальных ресурсов; 2) доминирующими общественными настроениями; 3 ) совокупностью внутренних и внешних факторов давления на общественно-политическую систему; 4) целями и задачами субъекта (актора) политической мобилизации.

Российская общественно-политическая система представляет собой синтез двух противоположностей: герметично «закрытую» институциональную политическую структуру и активную социальную составляющую, которые находятся в динамическом равновесии при последовательных «атаках» друг на дру- га. Цикличный характер «атак» определяется синусоидой смены массовых гражданских акций протеста на периоды репрессий. Невозможность инкорпорирования социальной активности в политическую систему современной России определяется характерными чертами «власти-моносубъекта». Власть в России исторически воспринимается как «единая и неделимая, качественно однородная» [10, c. 37]. Отсутствие строго определенных институциональных механизмов циркуляции элит приводит к изменению «паттернов представительства и участия» [19], что выражается в увеличении доли стихийных, неинституциональных форм участия. Симптоматично о подобных системах писал С. Хантингтон в книге «Политический порядок в меняющихся обществах»: «Темпы социальной мобилизации и роста политической активности населения высоки; темпы политической организации и институционализации низки. Результатом оказываются политическая нестабильность и беспорядок» [17, с. 25-26].

Специфика регионального публичного пространства Волгоградской области обусловлена как субъектным составом институционального дизайна регионального политического режима, так и характером сферы публичной политики, в том числе тематикой общественно-политического протеста. Институциональная специфика современного политического режима Волгоградской области обусловлена тенденциями как общефедерального, так и регионального уровней. Общефедеральные тенденции представляют собой особенности реализации общенационального политического курса в контексте осуществления политической модернизации России с учетом «неоднозначности реализации отечественной политической модернизации, незавершенности административной реформы» [9, с. 118]. Тенденции регионального уровня опосредованы изменением положения статусов различных институтов по отношению к процессу принятия решений (как политических, так и административно-политических), обусловленным сменой электорального цикла выборов главы региона, а также общественно-политической повесткой дня. Отметим, что адаптация институциональной системы регионального политического режима к общефедеральной 
системе «вертикали власти», ее практикам и инструментам мобилизации происходила в условиях ослабления демократичности и формирования сильного центра региональной власти. Так, примечательно, что на протяжении периода «губернаторов-варягов» в Волгоградской области фиксируется низкий уровень публичной ответственности перед обществом «у назначаемых губернаторов (как у А.Г. Бровко, так и у С.А. Боженова) отсутствует представление о подлинном носителе суверенитета и легитимности - обществе» [2, с. 293]. Данная тенденция может быть применена и к периоду первого срока полномочий А.И. Бочарова (даже несмотря на то что в сентябре 2014 г. он был избран губернатором Волгоградской области на досрочных выборах с результатом 88,49 \% при явке 38,72 \% [11]).

Региональное пространство публичной политики определено, с одной стороны, дублированием общероссийских тенденций, с другой - тематикой общественно-политической повестки дня, уникальной исключительно для Волгоградской области. Относительно первого тезиса авторы подразумевают издержки централизации региональных систем управления, что проявляется в политизации гражданского контроля и общественной экспертизы как наиболее целесообразных политических возможностей населения, позволяющих рационально оценить риски, издержки и возможные приобретения от мобилизационных действий. При этом публичная политика напрямую отражает достаточно сложные реалии политико-коммуникативных моделей, используемых различными акторами политического процесса в России. Вместе с тем, как отмечает С.И. Морозов, «явно проявляется недостаточно координированное взаимодействие отечественных государственных и негосударственных акторов; наблюдается отсутствие четких, институционально закрепленных “правил игры” в сфере информационного регулирования, обеспечения информационной безопасности» [6, с. 250]. Вследствие этого публичный протест олицетворяет для населения форму выражения недовольства существующей асистемности в политическом пространстве. Стоит отметить, что проблема институциональной несогласованности типична и для Волгоградской области, так как регио- нальный политический режим в большей части копирует общефедеральную систему осуществления власти.

При этом суть мобилизации протестующих имеет в том числе региональную специфику, которая основана на актуальных проблемах, специфичных для Волгоградской области. Стоит отметить, что в последние годы публичное пространство региона было обусловлено протестной тематикой. Так, по данным исследований АНО «Институт региональной экспертизы» за январь - апрель 2019 г., Волгоградскую область представляется возможным идентифицировать как наиболее протестный регион, который в отдельные периоды входил в «красную» группу [4; 12; 13; 14$]$. На основании данных, представленных в материалах АНО «Институт региональной экспертизы» за январь - апрель (наиболее актуальные данные) 2019 г., считаем целесообразным показать позицию Волгоградской области в сравнении с регионами, административным центром которых являются города-миллионники, обладающие наибольшим протестным потенциалом (Москва, Санкт-Петербург, Свердловская область), путем составления графика, в котором ось $X$ фиксирует период замера протестной активности, ось $Y$ - позицию в рейтинге по типу ранжируемости от 1 наиболее протестный регион, 85 - наименее протестный регион.

Визуализация графиков (сравнение показателей Волгоградской области и наиболее протестных регионов и сравнение показателей регионов Южного федерального округа) позволяет сделать вывод о том, что Волгоградская область хоть и имеет нисходящий тренд динамики протестной активности, но вместе с тем занимает высокую позицию среди крупнейших протестных регионов и ЮФО. Важно также отметить, что среди причин протестов в Волгоградской области за вышеуказанный период формирования рейтинга региональная тематика составила 57 \% в социально-экономическом блоке и 25 \% в политическом блоке. Данные обстоятельства указывают, что мобилизационные практики обусловлены как федеральными, так и региональными аспектами сферы публичной политики. Вместе с тем у авторов статьи нет оснований утвер- 


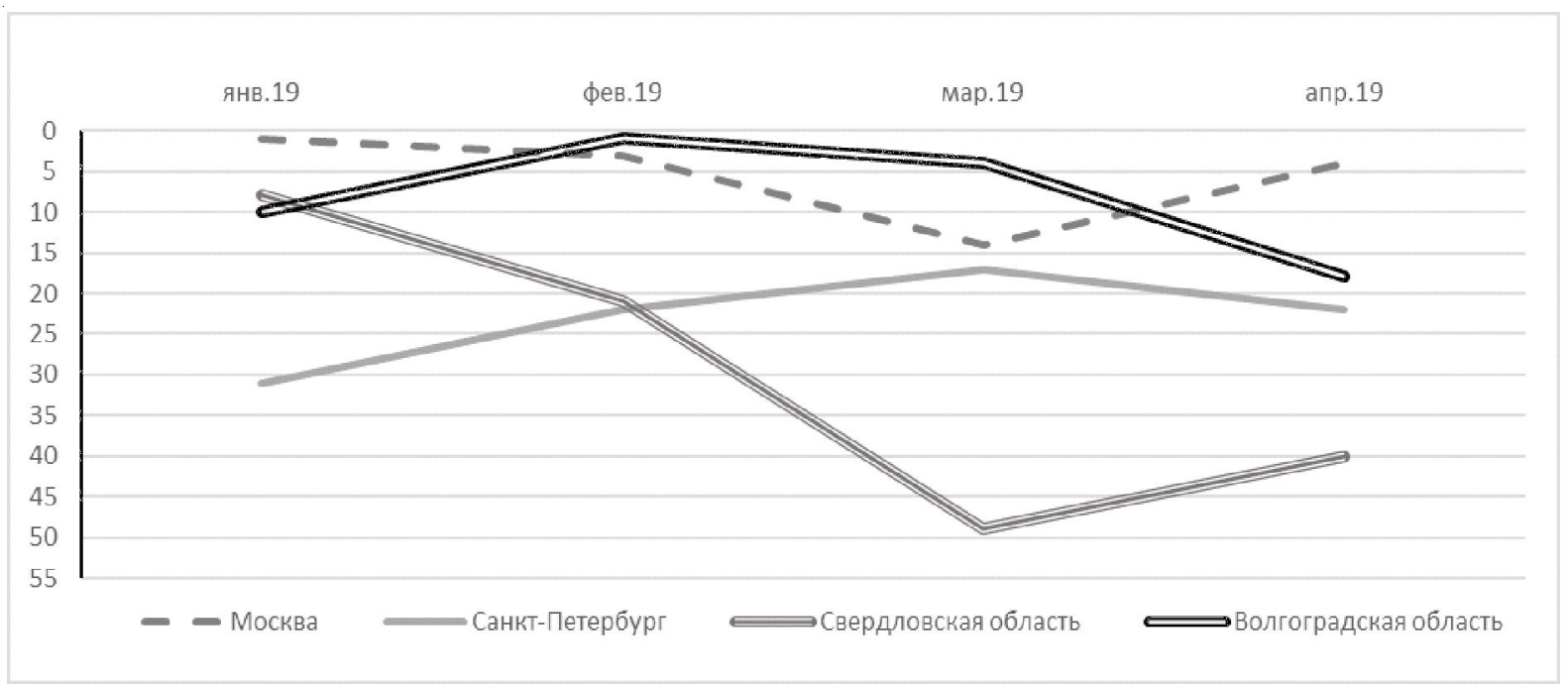

Рис. 1. Рейтинг протестной активности отдельных регионов Российской Федерации (сравнение показателей Волгоградской области и наиболее протестных регионов) за период январь - апрель 2019 г.

Fig. 1. Rating of protest activity of several regions of the Russian Federation (comparison of the indicators of Volgograd region and the most protest regions) for January-April 2019

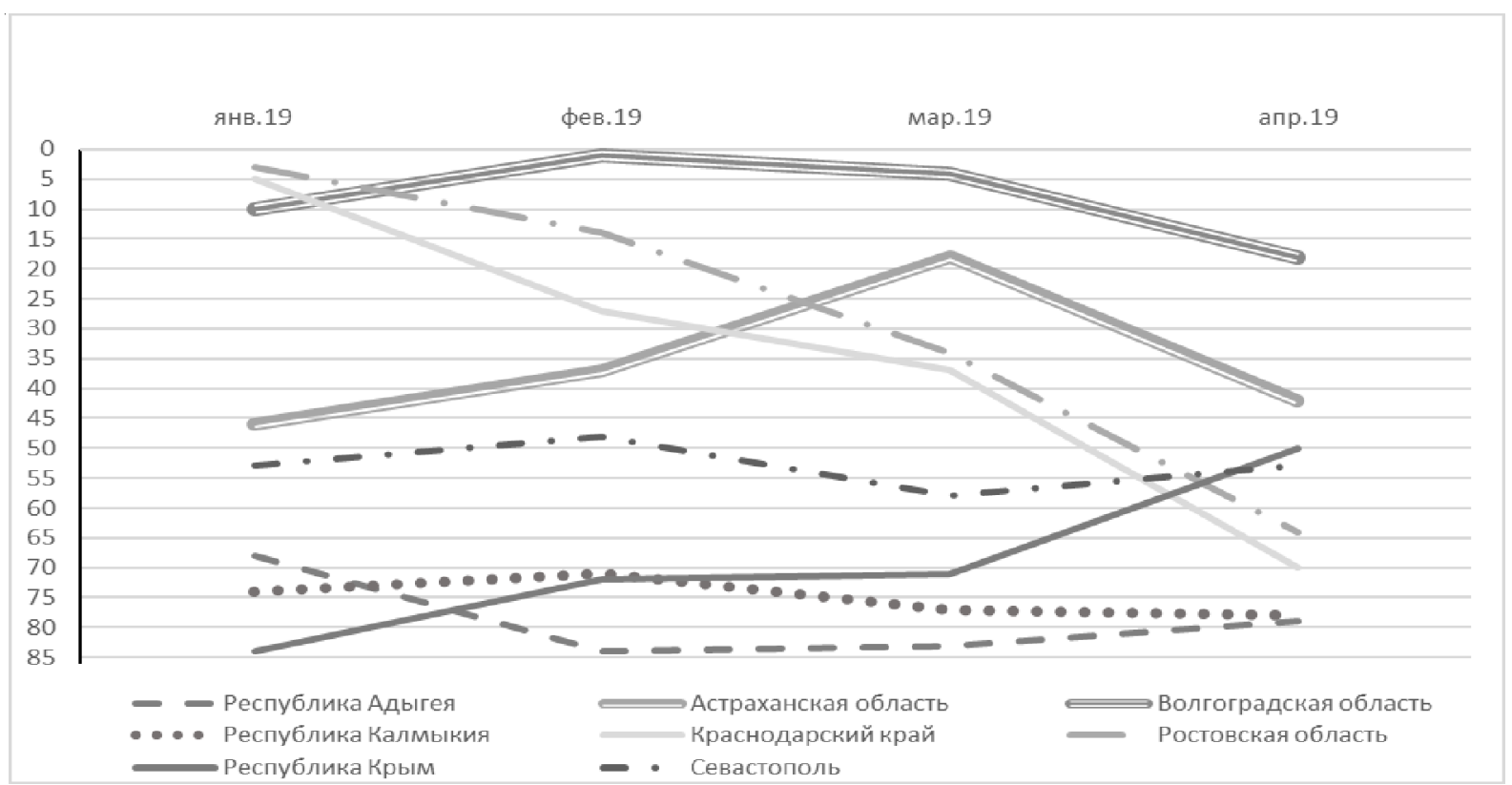

Рис. 2. Рейтинг протестной активности отдельных регионов Российской Федерации (сравнение показателей регионов Южного федерального округа) за период январь - апрель 2019 г.

Fig. 2. Rating of the protest activity of several regions of the Russian Federation (comparison of the indicators of Southern Federal District regions) for January-April 2019

ждать, что в волгоградских реалиях возможно создание мощных социальных движений (объединенных единой глобальной проблемой).

На основании данных, представленных на сайте Левада-центр [8], авторы на одной плоскости построили два графика: потенциал протеста с политическими требованиями и потенциал протеста с экономическими требованиями. Ось $X$ представленного графика фиксирует дату проведения опроса, ось $Y$ процент респондентов, положительно отвечавших на вопрос о готовности принять участие в протестах. 


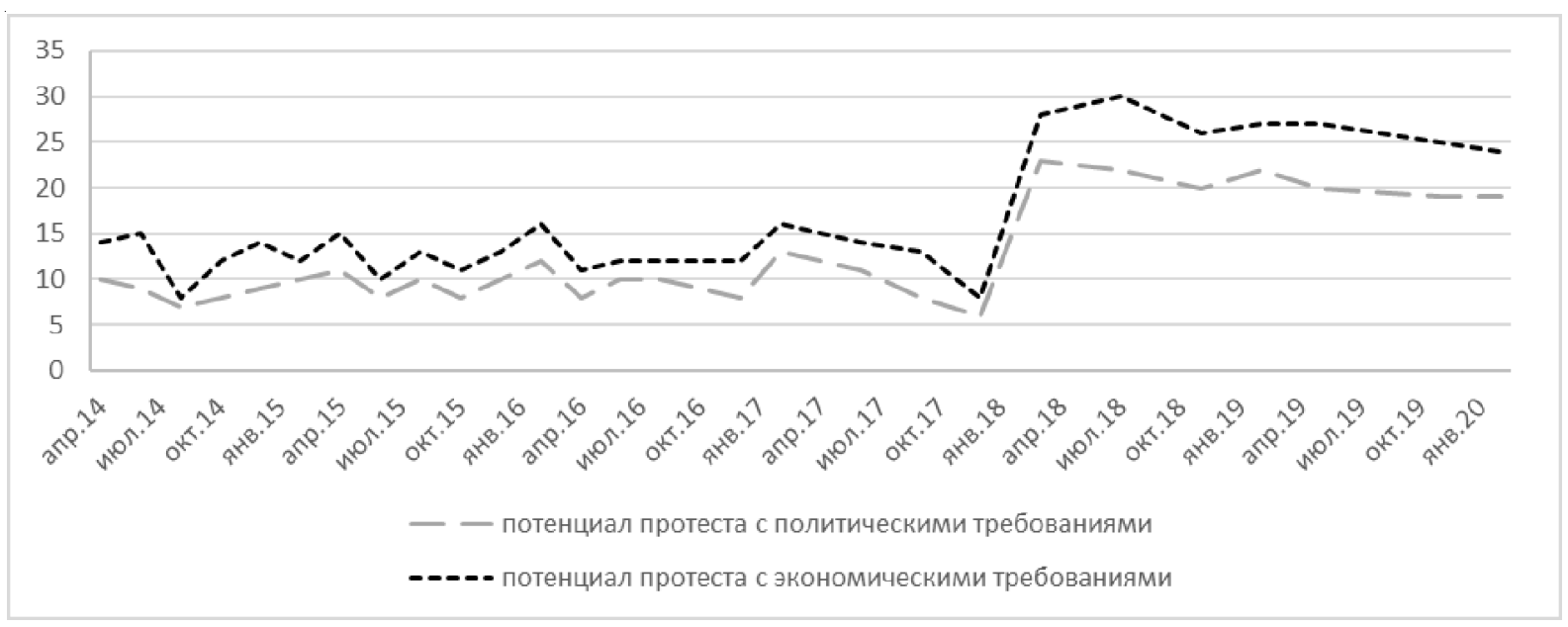

Рис. 3. Сравнение потенциала протеста с политическими и экономическими требованиями в Российской Федерации

Fig. 3. Comparison of protest potential with political and economic demands in the Russian Federation

Визуализация графика позволяет сделать вывод о приоритетном характере экономических проблем в современном российском обществе. Хоть графики и находятся в определенной корреляционной взаимосвязи, потенциал экономического протеста (в среднем на $5 \%$ в) выше политического.

Анализ и обработка местных протестных кейсов в Волгоградском регионе позволяет построить график, отражающий некоторые мобилизационные тренды местной публичной политики. Основанием графика послужили протестные кейсы за период с апреля 2014 г. (назначение А.И. Бочарова врио губернатора Волгоградской области), удовлетворяющие двум критериям: 1) масштаб участников акций свыше 100 человек; 2) широкий общественный резонанс (освещение событий в региональных СМИ).

Отбор событий осуществлялся на сетевом издании «В1.ру» [15], что обусловлено возможностью обеспечения расширенного поиска информации. Так, в качестве поискового запроса выступала единица счета - «массовый протест». В результате заданных характеристик поиска была сформирована база данных, представленная статьей 131 указанной тематики. В соответствии с обозначенными критериями был выделен ряд событий, зафиксированных на графике.

Таким образом, выделенные протестные события стали «точками» на графике. Ось $X$ отражает дату проведения протестной акции, ось $Y$ - диапазон участников (на графике представлена «верхняя планка» участников акций).

Как видно на графике, протестная динамика в Волгоградском регионе демонстрирует нисходящий тренд. Анализ выделенной совокупности протестных кейсов позволяет сделать следующие значимые выводы:

- из 12 массовых акций протеста 7 направлены на местные проблемы, 5 - региональное отражение общефедерального тренда, что подтверждает продолжающуюся тенденцию совмещения федеральной и региональной повестки дня в публичном пространстве Волгоградской области;

- наиболее массовая протестная акция (антикоррупционный митинг) 26 марта 2017 г. имела общефедеральный характер и являлась аномальной по количеству участников для Волгоградской области. Реальный масштаб протестующих, проявляющих фрустрацию в связи с проблемами местного характера, лишь единожды превысил 500 человек;

- протестная мобилизация по региональным проблемам имеет общий тренд: массовые акции имеют стихийный характер, коллективные действия организуются без поддержки институциональных структур;

- политический протест в Волгоградской области доминирует в практиках одиночных, либо малых групповых акций, именно данным фактом обусловлен «высокий» уровень 
Массовые протесты в Волгоградской области (2014-2020 гг.)

Mass protests in Volgograd region (2014-2020)

\begin{tabular}{|c|c|c|c|}
\hline $\begin{array}{c}\text { Дата проведения } \\
\text { акции }\end{array}$ & Цель мероприятия & $\begin{array}{l}\text { Количество } \\
\text { участников }\end{array}$ & Основание протеста \\
\hline 16 октября 2014 г. & $\begin{array}{l}\text { Митинг против строительства ресторана } \\
\text { KFC на территории парка в Спартановке }\end{array}$ & 300-400 человек & Экологическое \\
\hline 27 ноября 2014 г. & $\begin{array}{l}\text { Митинг за восстановление работоспособ- } \\
\text { ности «Химпрома» }\end{array}$ & 500-800 человек & Социально-экономическое \\
\hline 4 июля 2016 г. & $\begin{array}{l}\text { Митинг против новой транспортной сис- } \\
\text { темы }\end{array}$ & 500 человек & Социально-экономическое \\
\hline 26 марта 2017 г. & $\begin{array}{l}\text { Антикоррупционные митинги А.А. На- } \\
\text { вального }\end{array}$ & 800-1500 человек & Политическое \\
\hline 28 марта 2017 г. & «Протест маршрутчиков» & 200 человек & Социально-экономическое \\
\hline 2 апреля 2017 г. & Акция в поддержку политзаключенных & 200-300 человек & Политическое \\
\hline 2 апреля 2017 г. & $\begin{array}{l}\text { Митинг жителей Гумрака из-за работы по } \\
\text { реконструкции шоссе Авиаторов }\end{array}$ & 200 человек & Социально-экономическое \\
\hline 12 июня 2017 г. & $\begin{array}{l}\text { Митинг сторонников А. Навального на } \\
\text { площади Металлургов }\end{array}$ & 500 человек & Политическое \\
\hline 16 июня 2017 г. & $\begin{array}{l}\text { Стихийный митинг в п. им. М. Горького } \\
\text { из-за слухов о строительстве полигона } \\
\text { твердых бытовых отходов }\end{array}$ & 100 человек & Экологическое \\
\hline 28 июля 2018 г. & Митинг против пенсионной реформы & 500 человек & Социально-экономическое \\
\hline 11 августа 2018 г. & Митинг против пенсионной реформы & 100 человек & Социально-экономическое \\
\hline 16 апреля 2019 г. & Протест водителей «Яндекс.Такси» & 150 человек & Социально-экономическое \\
\hline
\end{tabular}

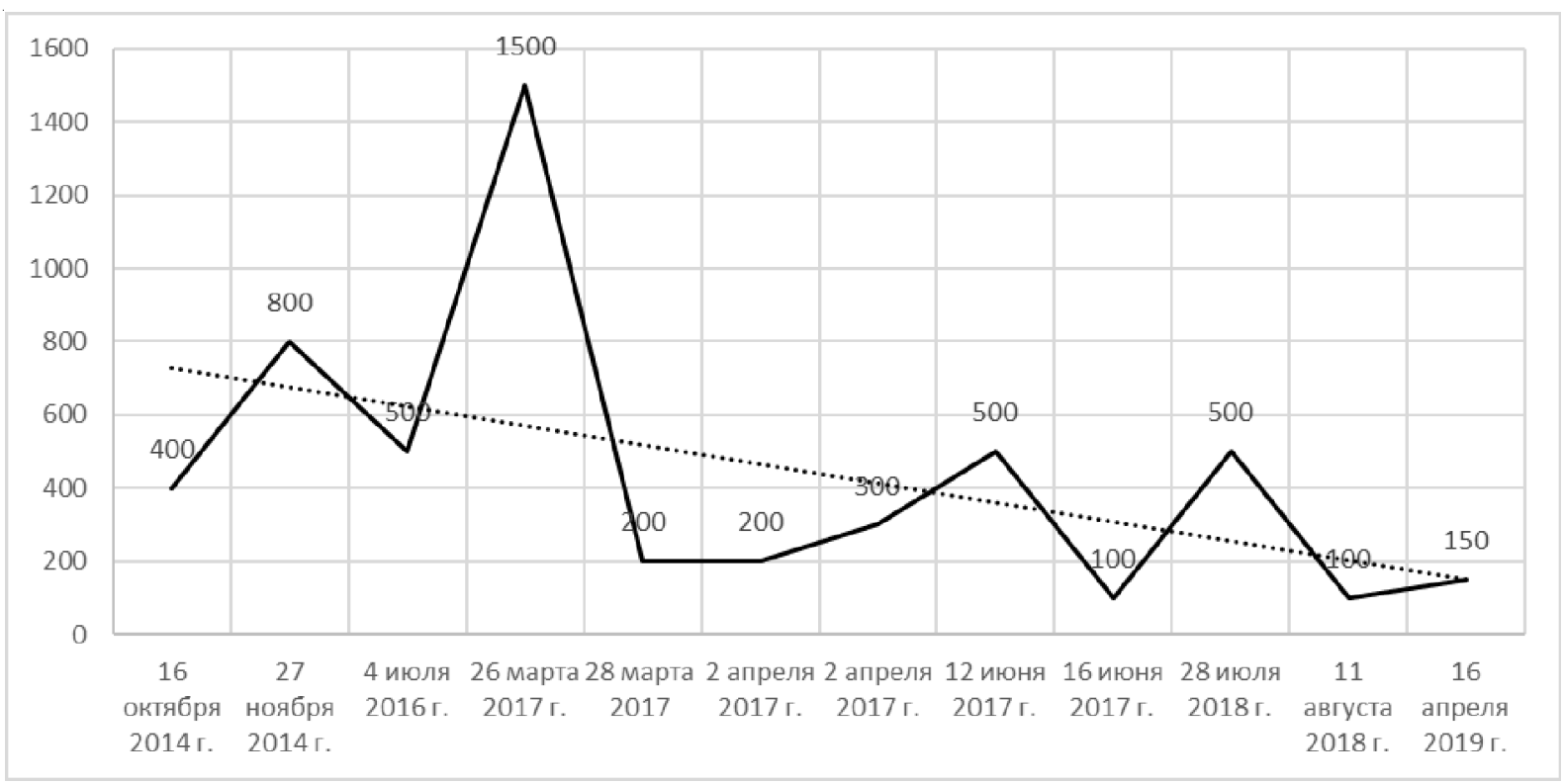

Рис. 4. Практики протестной мобилизации в Волгограде

Fig. 4. Practices of protest mobilization in Volgograd

протестности региона при низком количестве массовых публичных акций протеста.

Причины волгоградских массовых протестов имеют, как правило, социально-экономическое основание (приоритет экономических причин протеста совпадает с общефедеральной повесткой, представленной на рисунке 3 «Сравнение потенциала протеста с поли- тическими и экономическими требованиями в Российской Федерации»). Из 12 массовых протестных акций в Волгоградской области (с апреля 2014 по март 2020 г.), с определенными издержками, можно выделить 7 акций социально-экономического характера, 3 - политического и 2 - экологического. При этом стоит отметить, что любые проявления пуб- 
личной протестной активности имплицитно подразумевают политический характер в прямой пропорциональной зависимости от количества участников: чем больше количество участников протестной акции, тем выше степень ее политизации.

Среднее арифметическое от общего количества участников акций - 437,5 человек. При этом, если для чистоты исследования удалить из всей совокупности 1 наиболее (митинг 26 марта 2017 г.) и 1 наименее (митинг 16 июня 2017 г. или 11 августа 2018 г.) массовую акцию, то среднее количество участников уменьшается до 365 человек. Антикоррупционный митинг 26 марта 2017 г. - пиковая акция протестной мобилизации в Волгоградской области, после которой начался нисходящий мобилизационный тренд, вызванный исчерпанием ресурсной базы (социальной и организационной). Объяснение данному феномену исходит из природы (социальной, массовой, политической) мобилизации: индивиды готовы объединяться в группы и бороться, создавать институциональные структуры только в том случае, когда индивидуальные и групповые интересы будут совпадать. Схожая экономико-ориентированная логика была описана М. Олсоном: «[участники большой группы] не станут прилагать никаких усилий для достижения общегрупповых целей до тех пор, пока на них не будет оказано давление или каждому из них не будет предложен индивидуальный мотив к подобному действию» [7, с. 2].

Результаты. Характер протестной политической активности в публичном пространстве Волгоградской области обусловлен рядом социально-экономических и политических аспектов:

- во-первых, региональная система публичной политики проецирует общефедеральную тенденцию институциональной неопределенности и несогласованности акторов политического процесса;

- во-вторых, протестная активность определена совокупностью трех оснований социально-экономическими, политическими и экологическими проблемами общефедерального и регионального уровней;

- в-третьих, массовые акции имеют стихийный характер, коллективные действия орга- низуются без поддержки институциональных структур.

Протестная политическая мобилизация в регионе имеет ряд особенностей: превалирование местных проблем в протестном дискурсе, отсутствие сильных институциональных структур, способных мобилизовать материальные и организационные ресурсы (местное отделение КПРФ и штаб Навального в Волгограде дискредитировали себя для потенциального протестного электората и активизируют на социально-политическую активность лишь местных активистов), критически низкое для города-миллионника количество протестующих (из расчета среднего арифметического по всем массовым протестным акциям 2014-2020 гг.), стихийный (сиюминутный) характер мобилизации.

Низкий социальный потенциал протеста и отсутствие действенных механизмов политико-коммуникативного взаимодействия между институтами власти и представителями части общества, испытывающей фрустрацию по определенному кругу проблем публичного характера, актуализирует потребность в поиске иных методов диалогового общения в рамках представительной демократии. В соответствии с этим, считаем целесообразным рекомендовать органам региональной власти использовать в своей деятельности ресурсы общенациональных и региональных дискуссионных, консультационных площадок с целью повышения результативности управления социально-политическим протестами и выработки единых «правил игры» для всех акторов публичной политики. С целью минимизации рисков радикализации протеста и выстраивания позитивной публичной повестки в регионе считаем уместным предложить экспертноаналитическим центрам проявлять инициативу по внедрению современных разработок в области управления коллективными действиями и поведением масс. Региональным средствам массовой информации как основному субъекту трансляции информации необходимо придерживаться нейтральной тональности публикаций с целью сохранения стабильности коммуникационных стратегий акторов публичной политики и недопущения провокаций стихийных массовых акций. Институтам гражданской самоорганизации в Волгоградс- 
кой области при осуществлении публичной деятельности следует использовать ресурсы политической мобилизации, основанные на конструктивной публичной критике существующих системных проблем.

\section{ПРИМЕЧАНИЕ}

${ }^{1}$ Исследование выполнено при финансовой поддержке РФФИ и Администрации Волгоградской области в рамках научного проекта № 19-411340006 p_a «Социально-политическое проектирование публичного пространства и системы массовой коммуникации в регионах РФ (на примере Волгоградской области)».

The reported study was funded by RFBR and Volgograd Region Administration in the framework of research project no. 19-411-340006p_a "Socio-Political Design of Public Space and Mass Communication System in the Regions of the Russian Federation (The Example of the Volgograd Region)".

\section{СПИСОК ЛИТЕРАТУРЫ}

1. Блумер, Г. Коллективное поведение / Г. Блумер ; пер. с англ. Д. Водотынского // Американская социологическая мысль. - М. : Изд-во МГУ, 1994. C. $168-215$.

2. Гайворонский, Ю. О. Вызовы централизации и трансформации региональных политических режимов (на примере Волгоградской области) / Ю. О. Гайворонский // Политическая экспертиза: ПОЛИТЭКС. -2014. - Т. 10, № 1. -С. 281-296.

3. Гарр, Т. Р. Почему люди бунтуют / Т. Р. Гарр. - СПб. : Питер, 2005. - 461 с.

4. «Заметный март»: рейтинг протестной активности регионов РФ, март 2019 года // ИА REGNUM. - Электрон. текстовые дан. - Режим доступа: https://regnum.ru/news/polit/2609425.html (дата обращения: 28.02.2020). - Загл. с экрана.

5. Климов, И. А. Социальная мобилизация: к истории понятия / И. А. Климов // Человек. Сообщество. Управление. - 2004. - № 1. - С. 6-23.

6. Морозов, С. И. Практики взаимодействия государственных и негосударственных акторов в контексте регулирования системы массовой коммуникации в Российской Федерации / С. И. Морозов // Вестник Волгоградского государственного университета. Серия 4, История. Регионоведение. Международные отношения. - 2020. - Т. 25, № 1. - С. 241 253. - DOI: https://doi.org/10.15688/jvolsu4. 2020.1.20.

7. Олсон, М. Логика коллективных действий. Общественные блага и теория групп / М. Олсон. М. : ФЭИ, 1995. - 174 c.
8. Оценка текущего положения дел в стране: исследования аналитического центра Юрия Левады «Левада-центр». - Электрон. текстовые дан. Режим доступа: https://www.levada.ru/indikatory/ polozhenie-del-v-strane (дата обращения: 18.03.2020). - Загл. с экрана.

9. Панкратов, С. А. Система административнополитического управления в Волгоградской области: ресурсы и технологии модернизации / С. А. Панкратов, С. И. Морозов // Вестник Волгоградского государственного университета. Серия 4, История. Регионоведение. Международные отношения. - 2015. T. 20, №2 (32).-C. 118-121.

10. Пивоваров, Ю. С. «Русская Система» как попытка понимания русской истории / Ю. С. Пивоваров, А.И. Фурсов // Полис. Политические исследования. -2001 . - № 4. - С. 37-48.

11. Результаты выборов. Досрочные выборы Губернатора Волгоградской области. - Электрон. текстовые дан. - Режим доступа: http://www. volgograd.vybory.izbirkom.ru/region/region/ volgograd?action $=$ show $\&$ root $=1 \&$ tvd $=234200092$ $3659 \& \mathrm{vrn}=2342000923655 \&$ region $=34 \&$ global $=$ $\&$ sub_region $=34 \&$ prver $=0 \&$ pronetvd $=$ null $\&$ vibid $=$ $2342000923659 \&$ type $=234$ (дата обращения: 20.03.2020). - Загл. с экрана.

12. Рейтинг протестной активности регионов России, апрель 2019 года // ИA REGNUM. - Электрон. текстовые дан. - Режим доступа: https:// regnum.ru/news/polit/2626970.html (дата обращения: 20.03.2020). - Загл. с экрана.

13. Рейтинг протестной активности регионов России, февраль 2019 года // ИA REGNUM. - Электрон. текстовые дан. - Режим доступа: https:// regnum.ru/news/polit/2588639.html (дата обращения: 20.03.2020). - Загл. с экрана.

14. Рейтинг протестной активности регионов России, январь 2019 года // ИA REGNUM. - Электрон. текстовые дан. - Режим доступа: https:// regnum.ru/news/polit/2568900.html (дата обращения: 20.03.2020). - Загл. с экрана.

15. Сетевое издание «В1.ру». - Электрон. текстовые дан. - Режим доступа: https://v1.ru (дата обращения: 20.03.2020). - Загл. с экрана.

16. Тилли, Ч. От мобилизации к революции / Ч. Тилли ; пер. с англ. Д. Карасева ; под науч. ред. С. Моисеева ; Нац. исслед. ун-т «Высшая школа экономики». - М. : Изд. дом Высшей школы экономики, 2019. - 432 c. - DOI: https://doi.org/10.17323/ 978-5-7598-1527-3.

17. Хантингтон, С. Политический порядок в меняющихся обществах / С. Хантингтон. - М. : Прогресс-Традиция, 2004. - 480 c.

18. Хоффер, Э. Человек убежденный: личность, власть и массовые движения / Э. Хоффер. - М. : Альпина Паблишер, 2017. - 200 с. 
19. Fairbrother, P. Changing Patterns of Union Organisation? Representation and Participation: What is happening in Anglo-American Trade Union Movements? / P. Fairbrother // $18^{\text {th }}$ Annual International Labour Process Conference, April 25-27, 2000. Scotland : Univ. of Strathclyde, 2000.

20. Gupta, D. Understanding Terrorism and Political Violence: The Life Cycle of Birth, Growth, Transformation, and Demise / D. Gupta. - L. : Routledge, 2008. - 304 p.

\section{REFERENCE}

1. Blumer G. Kollektivnoe povedenie [Collective Behavior]. Amerikanskaya sotsiologicheskaya mysl [American Sociological Thought]. Moscow, Izd-vo MGU, 1994, pp. 168-215.

2. Gayvoronskiy Yu.O. Vyzovy tsentralizatsii i transformatsii regionalnykh politicheskikh rezhimov (na primere Volgogradskoy oblasti) [Challenges of Centralization and Transformation of Regional Political Regimes (On the Example of Volgograd Region)]. Politicheskaya ekspertiza: POLITEKS [Political Expertise: POLITEX], 2014, vol. 10, no. 1, pp. 281-296.

3. Garr T.R. Pochemu lyudi buntuyut [Why Men Rebel]. Saint Petersburg, Piter Publ., 2005. 461 p.

4. «Zametnyy mart»: reyting protestnoy aktivnosti regionov RF, mart 2019 goda [Noticeable March: Rating of the Protest Activity of the Regions of the Russian Federation, March 2019]. IA REGNUM [Regnum News Agency]. URL: https://regnum.ru/ news/polit/2609425.html (accessed 28 February 2020).

5. Klimov I.A. Sotsialnaya mobilizatsiya: $\mathrm{k}$ istorii ponyatiya [Social Mobilization: Toward a History of the Concept]. Chelovek. Soobshchestvo. Upravlenie [Human. Community. Management], 2004, no. 1, pp. 6-23.

6. Morozov S.I. Praktiki vzaimodeystviya gosudarstvennykh i negosudarstvennykh aktorov $\mathrm{v}$ kontekste regulirovaniya sistemy massovoy kommunikatsii v Rossiyskoy Federatsii [Practices of Interaction of State and Non-State Actors in the Context of Regulation of the Mass Communication System in the Russian Federation]. Vestnik Volgogradskogo gosudarstvennogo universiteta. Seriya 4. Istoriya. Regionovedenie. Mezhdunarodnye otnosheniya [Science Journal of Volgograd State University. History. Area Studies. International Relations], 2020, vol. 25, no. 1,pp. 241-253. DOI: https:// doi.org/10.15688/jvolsu4.2020.1.20.

7. Olson M. Logika kollektivnykh deystviy. Obshchestvennye blaga i teoriya grupp [Logic of Collective Action: Public Goods and the Theory of Groups]. Moscow, FEI, 1995. 174 p.

8. Otsenka tekushchego polozheniya del $v$ strane: issledovaniya analiticheskogo tsentra Yuriya
Levady "Levada-tsentr» [Assessment of the Current State of Affairs in the Country: Research by the Analytical Center of Yuri Levada "Levada Center"]. URL: https:/www.levada.ru/indikatory/polozheniedel-v-strane (accessed 18 March 2020).

9. Pankratov S.A., Morozov S.I. Sistema administrativno-politicheskogo upravleniya $\mathrm{V}$ Volgogradskoy oblasti: resursy i tekhnologii modernizatsii [The System of Administrative and Political Management in the Volgograd Region: Resources and Technologies of Modernization]. Vestnik Volgogradskogo gosudarstvennogo universiteta. Seriya 4. Istoriya. Regionovedenie. Mezhdunarodnye otnosheniya [Science Journal of Volgograd State University. History. Area Studies. International Relations], 2015, vol. 20, no. 2 (32), pp. 118-121.

10. Pivovarov Iu.S., Fursov A.I. «Russkaya Sistema» kak popytka ponimaniya russkoy istorii ["Russian System" as an Essay of Grasping Russian History]. Polis. Politicheskie issledovaniya [Polis. Political Studies], 2001, no. 4, pp. 37-48.

11. Rezultaty vyborov. Dosrochnye vybory Gubernatora Volgogradskoy oblasti [Election Results. Early Elections of the Governor of the Volgograd Region]. URL: http://www.volgograd. vybory. izbirkom.ru/region/region/volgograd?action= show \&root $=1 \& \mathrm{tvd}=2342000923659 \& \mathrm{vrn}$ $=2342000923655 \&$ region $=34 \&$ global $=\&$ sub_ region $=34 \&$ prver $=0 \&$ pronetvd $=$ null $\&$ vibid $=$ 2342000923659\&type $=234$ (accessed 20 March 2020).

12. Reyting protestnoy aktivnosti regionov Rossii, aprel 2019 goda [Rating of the Protest Activity of the Regions of Russia, April 2019]. IA REGNUM [Regnum News Agency]. URL: https://regnum.ru/ news/polit/2588639.html (accessed 20 March 2020).

13. Reyting protestnoy aktivnosti regionov Rossii, fevral 2019 goda [Rating of the Protest Activity of the Regions of Russia, February 2019]. IA REGNUM [Regnum News Agency]. URL: https://regnum.ru/news/ polit/2588639.html (accessed 20 March 2020).

14. Reyting protestnoy aktivnosti regionov Rossii, yanvar 2019 goda [Rating of the Protest Activity of the Regions of Russia, January 2019]. IA REGNUM [Regnum News Agency]. URL: https://regnum.ru/ news/polit/2568900.html (accessed 20 March 2020).

15. Setevoe izdanie "V1.ru» [Network Edition "V1.ru"]. URL: https://v1.ru (accessed 20 March 2020).

16. Tilly Ch. Ot mobilizatsii $k$ revolyutsii [From Mobilization to Revolution]. Moscow, Izdatelskiy dom Vysshey shkoly ekonomiki, 2019. 432 p. DOI: https:// doi.org/10.17323/978-5-7598-1527-3.

17. Khantington S. Politicheskiy poryadok $v$ menyayushchikhsya obshchestvakh [Political Order in Changing Societies]. Moscow, Progress- Traditsiya Publ., 2004. 480 p. 
18. Hoffer E. Chelovek ubezhdennyy: lichnost, vlast $i$ massovye dvizheniya [The True Believer: Thoughts on the Nature of Mass Movements]. Moscow, Alpina Pablisher Publ., 2017. 200 p.

19. Fairbrother P. Changing Patterns of Union Organisation? Representation and Participation: What Is Happening in Anglo-American Trade Union
Movements? 18 ${ }^{\text {th }}$ Annual International Labour Process Conference, April 25-27, 2000. Scotland, Univ. of Strathclyde, 2000.

20. Gupta D. Understanding Terrorism and Political Violence: The Life Cycle of Birth, Growth, Transformation, and Demise. London, Routledge, 2008. 304 p.

\section{Information About the Authors}

Sergey D. Gavrilov, Postgraduate Student, Senior Lecturer, Department of International Relations, Political Science and Area Studies, Volgograd State University, Prosp. Universitetsky, 100, 400062 Volgograd, Russian Federation, gavrilov_sd@volsu.ru, https://orcid.org/0000-0002-9098-8301

Kirill M. Makarenko, Postgraduate Student, Senior Lecturer, Department of International Relations, Political Science and Area Studies, Volgograd State University, Prosp. Universitetsky, 100, 400062 Volgograd, Russian Federation, makarenko_km@volsu.ru, https://orcid.org/0000-0002-1161-5719

\section{Информация об авторах}

Сергей Дмитриевич Гаврилов, аспирант, старший преподаватель кафедры международных отношений, политологии и регионоведения, Волгоградский государственный университет, просп. Университетский, 100, 400062 г. Волгоград, Российская Федерация, gavrilov_sd@volsu.ru, https://orcid.org/0000-0002-9098-8301

Кирилл Михайлович Макаренко, аспирант, старший преподаватель кафедры международных отношений, политологии и регионоведения, Волгоградский государственный университет, просп. Университетский, 100, 400062 г. Волгоград, Российская Федерация, makarenko_km@volsu.ru, https://orcid.org/0000-0002-1161-5719 